\title{
Effect of Defoliation Time on Depth of Dormancy and Bloom Time for Low- chill Peaches
}

Jon Lloyd and Daryl Firth

Tropical Fruit Research Station, New South Wales Agriculture and Fisheries, P.O. Box 72, Alstonville, NSW 2477 Australia

Additional index words. rest, hydrogen cyanamide, Prunus persica

Abstract. In a relatively low-chill environment, two cultivars of peach [Prunus persica (L.) Batsch] differing in chilling requirement ('Flordaprince', 150 units and 'Flordagold', 325 units) were defoliated at 10-day intervals during midautumn. Effects of defoliation on depth of bud dormancy and dose-dependent responses of cuttings to hydrogen cyanamide throughout the dormant period were analyzed to develop a dormancy index (DI). DI values indicate that early defoliation reduces depth of bud dormancy throughout winter for both cultivars. For 'Flordaprince', this was translated into early leafing and bloom, but fruit size was reduced by early relative to late defoliation. In contrast to 'Flordaprince', vegetative and floral budbreak of 'Flordagold' were delayed by early defoliation. These results indicate that early defoliation affects depth of dormancy and growth ability of buds, but that the extent to which these factors affect bud development depends on cultivar.

The release of commercially viable lowchill cultivars of stone fruit during the last 15 years has led to an expansion in production of peaches and nectarines in the tropics and subtropics (Sherman and Rodriguez-Al-

Received for publication 25 May 1989. This work was supported by the New South Wales Exotic Fruit Growers Association. The cost of publishing this paper was defrayed in pan by the payment of page charges. Under postal regulations, this paper therefore must be hereby marked advetisement solely to indicate this fact. cazar, 1987; Sherman et al., 1977). Although good prices and ready market demand serve to make stone fruit production in such regions profitable (Rom and Childers, 1988), production problems not usually encountered in more temperate regions exist. In particular, due to high temperatures and humidity in subtropical Australia, bacterial and fungal diseases are more prevalent than in traditional stone fruit growing regions. One consequence of the high disease pressure is often early defoliation due to diseases such as Xanthomonas pruni (bacterial spot),
Tranzschelia discolor (rust), and Stigmina carpophila (shot hole) (Bederski, 1987; do Carmo Bassols Raseira, 1988; George and Nissen, 1986: Munoz, 1988). Premature defoliation in tropical and subtropical situations often occurs despite extensive disease protection measures. II is, therefore, extremely difficult to keep leaves on trees up to the time of natural defoliation.

Time of defoliation has previously been observed to modify patterns of vegetative and reproductive growth in spring for deciduous trees growing in temperate climates, with early defoliation having been noted to delay spring bloom of peach (Couvillon and Lloyd, 1978). In contrast, others show that maintaining leaves on trees during autumn delays flowering. Apple trees with delayed autumn leaf abscission due to high autumn temperatures appear to have a greater chill requirement for budbreak than those exposed to lower temperatures during autumn (Chandler, 1960). Similarly, maintaining 'Elberta' peach trees at elevated temperatures during autumn and winter results in delayed leaf abscission and delayed floral budbreak the following spring (Walser et al., 1981). A small but significant delay in spring bloom induced by high autumn $\mathrm{N}$ applications (Reeder and Bowen, 1978) might also be a consequence of postponed defoliation. Autumn applications of GA, also delay leaf abscission and postpone budbreak the following spring (Walser et al., 1981).

In an effort to evaluate the effects of variations in defoliation time normally encountered in a subtropical climate (due to spatial and temporal differences in disease pressures and management practices), we examined responses to variations in defoliation time for 
Table 1. Meteorological data for Tuckombil experimental site during 1988. Chill units are calculated as either hours below 7.2C (Weinberger. 1950) or via the "Utah" (Richardson et al.. 1971) or "North Carolina" (Shaltout and Unrath, 1983) models. Using the Sharpe-Weinberger model used to assign chill units to Florida varieties (Sherman et al., 1978). 360 chili units accumulated in 1988 .

\begin{tabular}{|c|c|c|c|c|c|c|c|}
\hline \multirow[b]{2}{*}{ Month } & \multirow[b]{2}{*}{ Day no. } & \multicolumn{2}{|c|}{$\begin{array}{c}\text { Mean temp } \\
\left({ }^{\circ} \mathrm{C}\right)\end{array}$} & \multicolumn{3}{|c|}{ Chill units } & \multirow{2}{*}{$\begin{array}{c}\text { Rainfall } \\
(\mathrm{mm})\end{array}$} \\
\hline & & Max. & $\overline{\text { Min. }}$ & $\mathrm{Hrs}<7.2$ & "Uiah" & $"$ N. Carolina" & \\
\hline April & $92-121$ & 22.6 & 16.8 & 0 & 0 & 0 & 843 \\
\hline May & $122-152$ & 22.5 & 12.9 & 0 & 0 & 54 & 36 \\
\hline June & $153-182$ & 20.3 & 11.3 & 0 & 16 & 170 & 183 \\
\hline July & $183-213$ & 19.8 & 10.5 & 9 & 20 & 250 & 240 \\
\hline August & $214-244$ & 20.6 & 10.1 & 30 & 41 & 182 & 62 \\
\hline September & $245-274$ & 23.1 & 12.8 & 0 & 0 & 13 & 191 \\
\hline October & $275-305$ & 28.8 & 15.6 & 0 & 0 & 0 & 10 \\
\hline November & $306-335$ & 28.9 & 16.4 & 0 & 0 & 0 & 73 \\
\hline
\end{tabular}

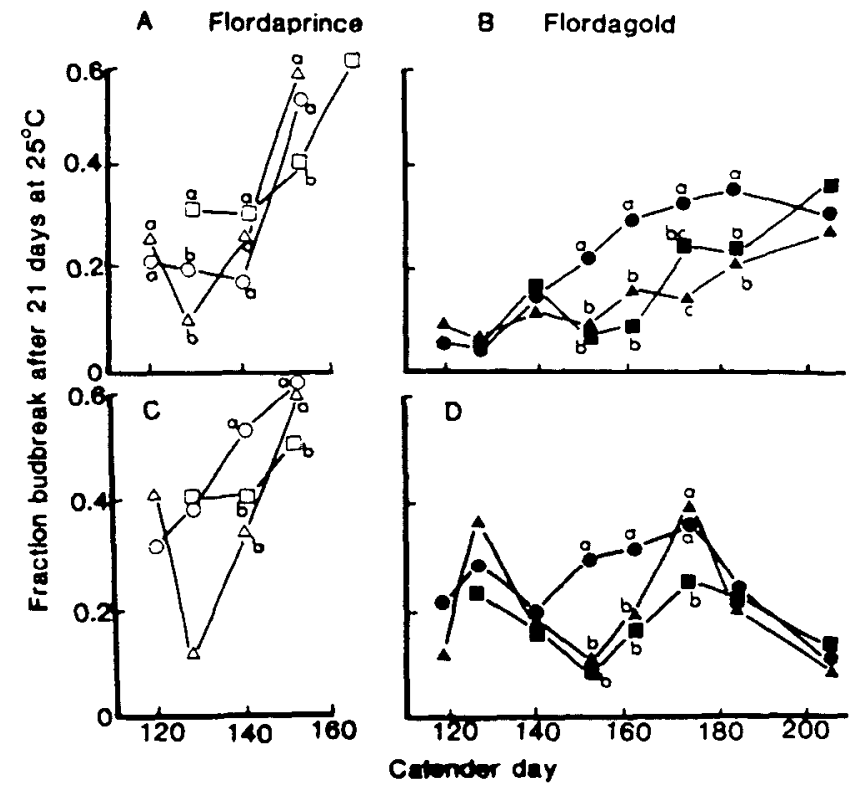

Fig. 1. Effect of defoliation time on budbreak of peach cuttings. (A) and (B) $0 \% \mathrm{H}_{2} \mathrm{NCN}$; (C) and (D) $0.25 \% \mathrm{H}_{2} \mathrm{NCN}$. Trees defoliated on day $105(\bullet)$ ); day $113(\boldsymbol{\Delta})$; day 123 ( $\boldsymbol{\square}$ ). On any day, only values accompanied by unlike letters differ significantly $(\mathrm{P}<0.05)$ after logistic transformation.

two peach cultivars differing in chill requirements. We also determined whether defoliation time influenced depth of dormancy of peach buds. This goal was achieved by examining budbreak in response to application of various concentrations of hydrogen cyanamide $\left(\mathrm{H}_{2} \mathrm{NCN}\right)$ throughout the dormant period.

This experiment was carried out using thirty 4- to 5-year-old 'Flordaprince' and 'Flordagold' peach trees growing in a commercial orchard near Alstonville in northeastern New South Wales $\left(29^{\circ} \mathrm{S}\right)$. 'Flordaprince' and 'Flordagold' have been assigned chill unit requirements of 150 and $325 \mathrm{hr}$, respectively, in Florida (Cracker and Sherman, 1983). AI three times during autumn (14 Apr., day 105; 22 Apr., day 113; 2 May, day 123) 10 trees of each cultivar were defoliated with $5 \% \mathrm{ZnSO}_{4}\left(=2 \mathrm{dm}^{3}\right.$ of solution per tree), which induced almost total defoliation within 4 days of spraying. Heavy rainfall in the previous 2 months $(463 \mathrm{~mm}$ ) had resulted in leaf diseases inducing $\approx 20 \%$ defoliation at the first treatment time (day 105). At the last treatment time (day 123), disease-induced leaf loss before spraying with $\mathrm{ZnSO}_{4}$ was estimated to be $40 \%$. Due to extreme tree-to- tree variation in rates of defoliation for non$\mathrm{ZnSO}_{4}$-treated trees, we did not closely monitor these trees, but observed them to show similar leafing and flowering patterns to trees defoliated on 2 May. budbreak besides its inducement of defoliation, three 'Flordaprince' trees were also defoliated by hand on day 113. Examination of return bloom dates showed no difference between manually and $\mathrm{ZnSO}_{4}$-defoliated trees.

For each cultivar, trees were randomized within single-tree plots. Due to limitations imposed on the experiment by the orchard layout, the two cultivars were in different regions of the orchard ( $\approx 200 \mathrm{~m}$ apart). Hourly temperatures were recorded using an electronic weather station (Peak et al., 1986). Rainfall data were obtained from the Tropical Fruit Research Station at Alstonville, 4 $\mathrm{km}$ south of the experimental orchard.

At intervals of $\approx 10$ days from 28 Apr. onwards, two twigs $\approx 30 \mathrm{~cm}$ long were cut from each tree (giving 20 twigs per treatment) and transferred 10 the laboratory. Four twigs from each treatment were then dipped for $\approx 30 \mathrm{sec}$ in either $0 \%, 0.125 \%$. $0.250 \%$, $0.500 \%$. or $1.0 \%$ hydrogen cyanamide
To determine if $\mathrm{ZnSO}_{4}$ had an effect on
$\left(\mathrm{H}_{2} \mathrm{NCN}\right)$. Cuttings were then placed in a 1$\mathrm{dm}^{3}$ beaker containing $\approx 100 \mathrm{~cm}^{3}$ of water, and extent of vegetative budbreak was determined after 21 days in a glasshouse at 25C. In general, extent of budbreak tended to increase with $\mathrm{H}_{2} \mathrm{NCN}$, but higher concentrations sometimes inhibited budbreak. A dormancy index (DI) was therefore calculated as follows:

$$
D I=\left[e^{[(H: N C N) / f}\right]-2
$$

where $\left[\mathrm{H}_{2} \mathrm{NCN}\right]$ is the concentration of $\mathrm{H}_{2} \mathrm{NCN}$ (in percent) inducing the maximum fraction $(f)$ of vegetative budbreak after 21 days. As endodormancy is often considered to be completed when $f=0.5$ after 21 days (George and Nissen, 1988), 2 was subtracted from $\mathrm{e}^{\left\{\mathrm{H}_{3} \mathrm{NCN} \mid\right.} / f$ to give DI $=0$ in this situation.

For 'Flordaprince', visual estimates of floral and vegetative budbreak were made at weekly intervals, starting 19 May. For 'Flordagold', two twigs on each of four trees per treatment were tagged, total numbers of vegetative and floral buds recorded, and subsequent vegetative and floral budbreak determined. Fruit were thinned in the normal commercial manner when fruit measured $\approx 10 \mathrm{~cm}^{3}$. Fruit volumes at harvest were determined from caliper measurements using equations for prolate spheroidal area for eight fruit per tree (Howie and Lloyd, 1989).

Budbreak data were subject to analysis of variance (ANOVA) by means of regression analysis using indicator variables on logistically transformed data using the GENSTAT binomial link function LOGIT. Mean separation was achieved via the $x^{2}$ statistic at $P=0.05$. Other data were subject to ANOVA with mean separation using Tukey's least significant range test at $P=0.05$.

Climatic conditions during the experiment are presented in Table 1. While the method of summating total hours below 7.2C (Weinberger, 1950) and the "Utah" model (Richardson et al., 1974) gave similar estimates of total chill units received (39 and 77 units, respectively), the "North Carolina" model (Shaltout and Unrath, 1983) gave a higher value (669 chill units). Using the SharpeWeinberger model used to assign chill units to Florida cultivars (Sherman et al., 1978), 360 chill units accumulated in 1988. Rainfall in 1988 was much greater than usual for the 
Table 2. Effect of defoliation time on bloom time and fruit volumes at harvest for 'Flordaprincc' and 'Flordagold' peach.

\begin{tabular}{lcc}
\hline \hline $\begin{array}{l}\text { Defoliation time } \\
\text { (calendar day) }\end{array}$ & Flordaprince & Flordagold \\
\hline \multicolumn{3}{c}{ Time of floral budbreak (calendar day) } \\
105 & $162 \mathrm{a}$ & $240 \mathrm{~b}$ \\
113 & $167 \mathrm{~b}$ & $225 \mathrm{a}$ \\
123 & $180 \mathrm{c}$ & $221 \mathrm{a}$ \\
\multicolumn{4}{c}{ Fruit volume al harvest $\left(\mathrm{cm}^{3}\right)$} \\
105 & $47.5 \mathrm{a}$ & $67.0 \mathrm{a}$ \\
113 & $59.5 \mathrm{~b}$ & $83.7 \mathrm{a}$ \\
123 & $60.2 \mathrm{~b}$ & $71.3 \mathrm{a}$ \\
\hline
\end{tabular}

${ }^{\mathrm{z}}$ Mean separations within columns by Tukcy's least significant range test $(P=0.05)$

${ }^{\mathrm{y}}$ Day $105=14$ Apr.; day $113=22$ Apr.; day $123=2$ May.

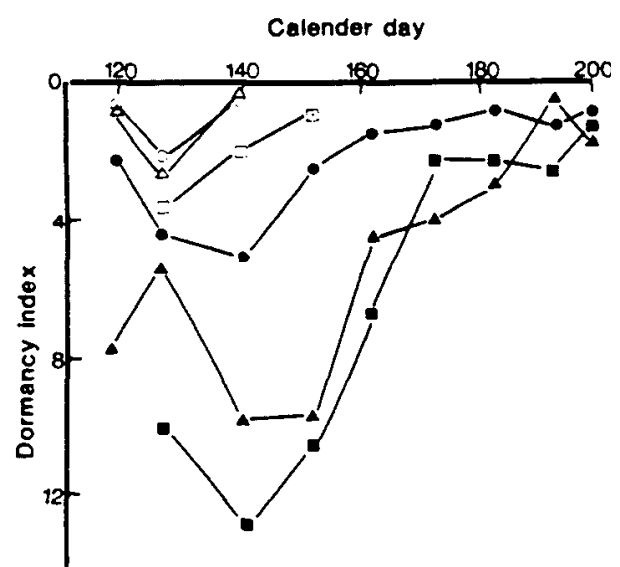

Fig. 2. Effect of defoliation time on depth of dormancy of 'Flordaprince' (open symbols) and 'Flordagold' (closed symbols) buds. Trees defoliated on day 105 ( ); day $113(\boldsymbol{\Delta}$ ); day 123 ( $\mathbf{\square})$.

north coast of New South Wales, especially in April.

Bud-forcing studies. Effect of defoliation time on subsequent bud development strongly depended on cultivar. Irrespective of defoliation time and within 40 days of defoliation, 'Flordaprince' cuttings not treated with $\mathrm{H}_{2} \mathrm{NCN}$ had $f>0.5$ after 21 days at $25 \mathrm{C}$ (Fig. 1A). $\mathrm{H}_{2} \mathrm{NCN}$ stimulated budbreak throughout the study period for trees defoliated on any of the three dates (Fig. 1C).

Budbreak immediately after defoliation occurred to a lesser extent for 'Flordagold'. There were, however, significant effects of defoliation time on budbreak in the absence of $\mathrm{H}_{2} \mathrm{NCN}$ after day 150 (Fig. 1B). For trees defoliated on day $105, f$ was significantly greater than for those defoliated on the two later dates (Fig. 1B). $\mathrm{H}_{2} \mathrm{NCN}$ stimulated budbreak for all three defoliation times up to day 140 , after which little effect of $\mathrm{H}_{2} \mathrm{NCN}$ was apparent; $\mathrm{H}_{2} \mathrm{NCN}$ actually inhibited budbreak of 'Flordagold' toward the end of the dormant period (day 210, Fig. 1D).

Both duration and depth of dormancy, as expressed by the DI, were less for 'Flordaprince' than 'Flordagold' (Fig. 2). For 'Flordaprince', trees defoliated on day 123 had a greater depth of dormancy that was broken at a later date than among those defoliated on days 105 and 113. Similar effects of de- foliation time on depth of dormancy were apparent for 'Flordagold', with trees defoliated at the latter two times having markedly higher DI values. After day 172, there was no significant effect of defoliation time on DI values, which then were low and changed little over the next 30 days.

Bloom dates for 'Flordaprince' were markedly advanced by early defoliation. In contrast, budbreak was delayed in 'Flordagold' by early defoliation (Table 2). For both 'Flordaprince' and 'Flordagold', defoliation time affected vegetative bud development in a similar manner to that observed for floral buds (data not shown).

Despite equivalent crop loads, fruit on 'Flordaprince' trees defoliated on day 105 were smaller at harvest than fruit on trees of this cultivar defoliated on the two later dates. There was no effect of defoliation time on fruit volume at harvest for 'Flordagold' (Table 2).

Immediately after the first defoliation, budbreak of 'Flordaprince' under glasshouse conditions at $25 \mathrm{C}$ was $<50 \%$ after 21 days (Fig. 1A). By currently accepted criteria (Saure, 1985) for all three defoliation times, buds were in a state of endodormancy rather than being in a state of paradormancy (correlative inhibition) before defoliation. This proposition is strengthened by the observation that $\mathrm{H}_{2} \mathrm{NCN}$ applications stimulated bud break for twigs sampled just after defoliation (Fig. 1C). Before endodormancy, $\mathrm{H}_{2} \mathrm{NCN}$ is ineffective in stimulating the growth of vegetative buds (Fuchigami and Nee, 1987).

At all three defoliation times, 'Flordaprince' buds had broken dormancy by day 150. No hours below 7.2C had accumulated by this time, and the "Utah" model had failed to reach the point where chill units start accumulating. In contrast, the "North Carolina" model had accumulated 52 chill units at the end of May (day 152; Table I), possibly because temperatures in the range 12 to $15 \mathrm{C}$ enhance chilling effects incurred at lower temperatures (Couvillon and Erez, 1985; Erez et al., 1979). This discrepancy between model predictions and actual date of dormancy termination may be due to 'Flordaprince' being a very low-chill cultivar with chilling requirements in Florida stone fruit cultivars being evaluated via measurement of average temperature in the coldest month of the year and bloom time (Sherman and Rodriguez-Alcazar, 1987), rather than according to the more complicated models. Both the "Utah" and "North Carolina" models were derived using high-chill apple or peach cultivars as experimental material There is presently no evidence to suggest that low-chill cultivars have the same temperature response for chill unit accumulation as higher chill cultivars.

Because excised branches have a limited life, enhanced budbreak at a range of $\mathrm{H}_{2} \mathrm{NCN}$ concentrations provided an early indication of the physiological status of buds. This approach is similar to that employed by Hatch and Walker (1969) using GA, but avoids the criticism that gibberellins may only be required for later steps of bud development, after dormancy has been terminated (Lavender and Silim, 1987; Saure, 1985). We used the exponential function in Eq. [1] to take into account differences in budbreak that occur when $\mathrm{H}_{2} \mathrm{NCN}$ is ineffective in stimulating budbreak.

Despite buds of both 'Flordaprince' and 'Flordagold' being endodormant before defoliation, examination of DI values showed that depth of dormancy increased after defoliation and that the extent of this effect depended on both cultivar and date of defoliation. For the lower chill 'Flordaprince', buds consistently were less dormant and overcame rest at an earlier date than 'Flordagold'. Although cultivar differences were apparent for all three defoliation times, earlier defoliation reduced depth of bud dormancy for both cultivars. While a lower depth of dormancy was translated into earlier budbreak for 'Flordaprince', the opposite was true for 'Flordagold'. This indicates that for 'Flordagold' early defoliation reduced growth ability of buds as well as depth of dormancy.

The strong interaction between cultivar and response to defoliation may be attributable to buds of the two cultivars being at a different developmental state on any defoliation date, perhaps as a consequence of differences in depth of dormancy at time of defoliation (Fig. 2). Recent studies using lowchill apples (J. Lloyd and J. Slack, unpublished data) over a longer period than used in this study (9 weeks), showed that defoliation at an early stage of bud development delays budbreak in spring, but that for trees defoliated closer to the time of natural defoliation, bloom dates are markedly advanced over naturally defoliated controls.

\section{Literature Cited}

Bederski, K. 1987. Selection and dormancy management of temperature zone deciduous fruit tree cultivars in coastal valleys of Peru. Acta Hort. No. 199.

Chandler, W.H. 1960. Some studies of rest in apple trees. Proc. Amer. Soc. Hort. Sci. 110:4750.

Couvillon, C.A. and A. Erez. 1985. Effect of level and duration of high temperatures on rest in the peach. J. Amer. Soc. Hort. Sci. 110:579-581.

Couvillon, G.A. and D.A. Lloyd. 1978. Summer defoliation effects on spring bud development. HortScience 13:53-54.

Cracker, T.E. and W.B. Sherman. 1983. Peaches and nectarines in Florida. Coop. Ext. Serv., Univ. of Florida, IFAS Circ. 229-C.

do Carmo Bassols Rasiera, M. 1988. Peach cultivars, breeding and culture in Brazil, p. 147154. In: N.F. Childers and W.B. Sherman (eds.). The peach. Horticultural Publications, Gainesville, Fla.

Ercz, A., G.A. Couvillon, and C.H. Hendershott. 1979. The effect of cycle length on chilling negation by high temperatures in dormant peach buds. J. Amer. Soc. Hort. Sci. 104:573-576.

Fuchigami, L.H. and C-C. Nee. 1987. Degree growth stage model and restbreaking mechanisms in temperate woody perennials. HortScience 22:836-845.

George, A.P. and R.J. Nissen. 1986. Low chill peach and nectarine cultivars. Queensland Agr. J. 112:27-33.

George, A.P. and R.J. Nissen. 1988. Chemical methods of breaking dormancy of low-chill nec- 
tarines: preliminary evaluations in sub-tropical Queensland. Austral. J. Expt. Agr. 28:425-429.

Hatch, A.H. and D.R. Walker. 1969. Rest intensity of dormant peach and apricot leaf buds as influenced by temperature, cold hardiness and respiration. J. Amer. Soc. Hort. Sci. 94:304 307.

Howie, H. and J. Lloyd. 1989. Response of orchard 'Washington Navel' orange to saline irrigation water II. Flowering, fruit set and fruit growth. Austral. J. Agr. Res. 40, 371-380.

Lavender, D.P. and S.N. Silim. 1987. The role of plant growth regulators in dormancy in forest trees. Plant Growth Reg. 6:171-191.

Munoz, C.E. 1988. Peach breeding and culture in Brazil, p. 155-159. In: N.F. Childers and W.B Sherman (eds.). The peach. Horticultural Publications, Gainesville, Fla.

Peak, C.M., R.D. Fitzcell, R.S. Hannah, and D.J. Batten. 1986. Development of a microproces- sor-based data recording system for predicting plant disease based on studies on mango anfhracnose. Computers and Eletronics in Agriculture 7:251-262.

Reeder, B.D. and H.H. Bowen. 1978. Effect of nitrogen applications on bloom delay and levels of abscisic acid. carbohydrates and nitrogen in peach buds. J.. Amer. Soc. Hort. Sci. 103:745749.

Richardson, E.A., S.D. Seeley, and D.R. Walker. 1974. A model for estimating the completion of rest for 'Redhaven' and 'Elberta' peach trees. HortScience 9:331-332.

Rom, C.R. and N.F. Childers. 1988. Temperate fruits in the tropics. Venezuela, p. 142-146. In: N.F. Childers and W.B. Sherman (eds.). The peach. Horticultural Publications. Gainesville, Fla.

Saure, M. 1985. Dormancy release in deciduous fruit trees. Hort. Rev. 7:239-300.

Shaltout, A.D. and C.R. Unrath. 1983. Rest com- pletion model for 'Starkrimson Delicious' apples. J. Amer. Soc. Hort. Sci. 108:957-961.

Sherman, W.B., R.J. Knight, and T.E. Crocker. 1978. Peach and nectarine breeding and testing in warm parts of the world. Proc. Trop. Reg. Amer. Soc. Hort. Sci. 22:103-117.

Sherman, W.B., J. Soule, and P. Andrews. 1977 Distribution of Florida peaches and nectarines in the tropics and subtropics. Fruit Var. J. 31:7578.

Sherman, W.B. and J. Rodriguez-Alcazar. 1987. Breeding of low chill peach and nectarine for mild winters. HortSciencc 22:1233-1236.

Walser, R.H., D.R. Walker, and S.D. Seeley. 1981. Effect of temperature, fall defoliation and gibberellic acid on the rest period of peach buds. J.. Amer. Soc. Hort. Sci. 106:91-94.

Weinberger, J.H. 1950. Chilling requirements of peach varieties. Proc. Amer. Soc. Hort. Sci. 94:304-307. 